\title{
Banteng and Bali Cattle in Indonesia: Status and Forecasts
}

B Purwantara, R R Noor, G Andersson and Heriberto Rodriguez-Martinez

\section{Linköping University Post Print}

N.B.: When citing this work, cite the original article.

This is the authors' version of the following article:

B Purwantara, R R Noor, G Andersson and Heriberto Rodriguez-Martinez, Banteng and Bali Cattle in Indonesia: Status and Forecasts, 2012, Reproduction in domestic animals (1990), (47), SI, 2-6.

which has been published in final form at:

http://dx.doi.org/10.1111/j.1439-0531.2011.01956.x

Copyright: Blackwell Publishing

http://www.blackwellpublishing.com/

Postprint available at: Linköping University Electronic Press

http://urn.kb.se/resolve?urn=urn:nbn:se:liu:diva-74150 


\title{
Banteng and Bali cattle in Indonesia: Status and forecasts
}

\author{
Purwantara $\mathrm{B}^{1^{*}}$, Noor $\mathrm{RR}^{2}$, Andersson $\mathrm{G}^{3}$, Rodriguez-Martinez $\mathrm{H}^{4}$ \\ ${ }^{1}$ Dept of Veterinary Clinic, Reproduction and Pathology, Faculty of Veterinary Medicine, \\ Bogor Agricultural University, Bogor, Indonesia; ${ }^{2}$ Research \& Community Services Institute, \\ Bogor Agricultural University, Bogor, Indonesia; ${ }^{3}$ Dept of Animal Breeding and Genetics, \\ Swedish University of Agricultural Sciences, Uppsala, Sweden; ${ }^{4}$ Dept of Clinical \& \\ Experimental Medicine, University of Linköping, Linköping, Sweden.
}

Running title: Bali cattle breeding: state of the art

\section{Contents}

Bali cattle still represents $27 \%$ of the total cattle population in Indonesia, and it is considered the pillar breed for small farmers. Moreover, it is a breed of evolutionary importance regarding its direct ancestry from Banteng. However, there is a need for the establishment of a rational system for the evaluation of breeding soundness for indigenous Bali bulls to be used as sires for artificial insemination breeding programmes. Moreover, there is a need for cryobanking of well identified genetic resources pertaining their use in evolutionary research and application as essential germplasm in breeding programmes.

Key words: livestock rearing, banteng, bali cattle, breeding, Indonesia.

\section{Introduction}

Cattle production in Indonesia is generally based on indigenous and imported breeds, the first named usually extensively managed on natural pasture. Bali cattle (Bos sondaicus, Bos javanicus, Bos/Bibos banteng), a domesticated descendant of the wild Banteng (Bibos banteng) represents about $27 \%$ of the total cattle population in Indonesia (about 11 million heads in 2004). Bali cattle is the most preferred in the small holding system, due to their rusticity, fertility and low calf mortality and breeding programmes have slowly been built in the country using artificial insemination (AI) with frozen-thawed semen from, largely, phenotypically-selected bull sires. Owing to the randomized application of expansion programmes, and the presence of ill-explored remnants of Banteng colonies in national parks, there is no detailed knowledge of the genetic complexity and purity of these individual species, a pre-requisite when cryobanking of genetic resources and/or their application in breeding programmes is to be attempted.

\section{Banteng}

Banteng (Order: Artiodactyla, Family: Bovidae, Subfamily: Bovinae, Genus: Bos, Subgenus: Bibos), an endangered asian wild cattle, is most likely the ancestor to the domestic cattle of Southeast Asia (Nowak, 1991). Banteng is a sexually-dimorphic species, with mature males 
being dark chestnut brown and cows and juveniles reddish brown. Both sexes have white rump patches and leggings, carry horns, the latter being much more heavier and larger in males. Adult male Bantengs weigh between 600 and $800 \mathrm{~kg}$, while adult females range 590$670 \mathrm{~kg}$. Their average lifespan in the wild is 11 years, although they can live to 20-25 years of age. It is very common for captive banteng to live into their late teens or mid-twenties. The world population of Banteng is considered to range 5-8,000 heads (2000 IUCN Red Data List) being located in Bangladesh, Brunei Darussalam, Cambodia, India, Indonesia (Kalimantan, Java and Bali), Lao People's Democratic Republic, Malaysia, Myanmar, Thailand and Viet Nam (see map) (Wilson and Reeder, 1993) The known subpopulations in the wild are small (5-6 stable subgroups in Java, having more than 50 Banteng/group) and decreasing in most countries (illegal hunting and habitat destruction, mainly but also due to diseases spread from domestic livestock). Banteng has been introduced in other territories (Northern Territory of Australia) in large numbers (up to 400 animals). Wild Banteng build herds of 10 to 30 animals; about one-third of herds contain ten or more individuals, about one-third of the herds contain six to nine individuals, and about one-third of the herds contain five or fewer individuals. The Banteng usually graze in open, dry, deciduous forests whenever present. Although grazers by preference, they consume other material (fruits, browse) depending on availability. The Banteng is legally protected (classified by the IUCN Red Data List as endangered, albeit not listed by CITES) and occurs in a number of protected areas. There is a large captive population, owing to protected fields (natural parks and extense zoos) as well as in zoological gardens all over the world (up to nearly 2,000 animals, International Studbook for Banteng) since they are easily managed in captivity, where they reproduce well and can live into their early twenties.

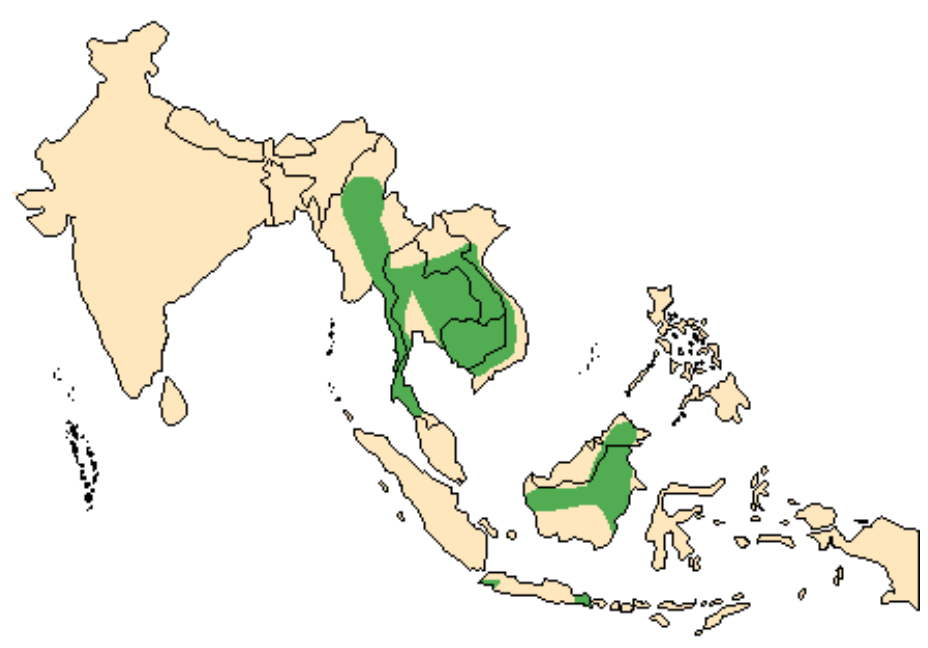

Figure 1: approx. distribution of Banteng (Bos/Bibos banteng) in Southeast Asia.

As a consequence of the development of captive breeding programmes in many countries problems have emerged. Interbreeding with domestic and feral cattle threatens the genetic integrity of the remaining wild Banteng and questions concerning the purity of the genetic status of the captive population are evident. Many founder animals for the captive population were Bali cattle, which is the domesticated form of the wild Banteng. Because Banteng can interbreed with common cattle, there exists the possibility that captive populations may contain genetic material from Bali cattle/Bos taurus crosses. There is an obvious need to 
further assess the genetic and phenotypic variation within the global population of wild Banteng in order to determine the validity of the three subspecies traditionally recognized among Banteng but also to disclose the genetic status of the remaining population, in order to allow the safe collection and cryobanking of pure genetic material for future generations.

\section{Bali cattle}

\section{Origin and distribution}

Bali cattle (Bos sondaicus, Bos javanicus, Bos/Bibos banteng) is one of the important beef cattle breeds contributing to the development of livestock industries in Indonesia. Beside in Bali Island itself, Bali cattle is the most predominant breed in most of the eastern islands. Three major foci of Bali cattle population is South Sulawesi, East and West Nusa Tenggara and the numbers there now exceed those in Bali (Anonymous 2004). Bali cattle are also distributed to a number of areas of Sumatera such as Lampung, Bengkulu and South Sumatera as well as south and central Kalimantan. Transmigration program in early 1970's had a specific role on the acceleration of Bali cattle distribution in other geogrphical locations than in Bali. Bali cattle are well adapted to the tropics and are indigenous to Southeast Asia. Their morphological characteristics differ markedly from those of Bos taurus and Bos indicus (Talib et al. 2002a). Their coat colour is very distinctive, usually reddish-brown, except for a clearly defined white area on the hindquarters that extends along the belly, and also white socks reaching from the hooves to just above the hocks. In bulls, but not in females, the red hair covering the whole of the body begins to darken at 12-18 months of age and by time of matururity is almost black. In castrated bulls, black hair on the whole body changes to red again within a few months of castration. These are humpless cattle, the body being relatively large framed and well muscled, with good hind-quarters (Talib et al 2002a). The male F1generation crossbreds between Bos sondaicus and Bos taurus has been regarded as infertile, although this finding is based on a very small sample size (Talib et al 2002a). Kirby et al. (1979) reported that all F1 1/4 Bali and 3/4 Bali bulls resulting from Brahman/ Shorthorn cattle were infertile, although some semen was present in $1 / 4$ Bali bulls. All of the crossbred females were fertile. Karyotype studies show that the $\mathrm{Y}$ sex chromosome of Bos sondaicus is apparently identical to that of Bos taurus, but not to that of Bos indicus (Kirby 1979). Kikkawa et al. (1995, cf Talib et al. 2002b) by using RFLPs of cDNAs prepared from mRNA and the sequences of mitochondrial genes for cytochrome b had concluded that Bos sondaicus (Bali cattle) had a different ancestor from that of European and Zebu cattle. There is a need to disclose the genetic status as outlined above of the Bali cattle population, to define the genetic variation and complexity and to contribute to an improved knowledge of evolutionary genetics of Bali cattle.

\section{Economic importance and sustainability}

Due to the increasing demand for beef in recent years, beef cattle are considered as a strategic commodity in developing the livestock industry. Unfortunately, national production of beef has never met the demand of Indonesia. Among other beef breeds, Bali cattle have dominated the cattle population outside Java, primarily in eastern islands of Indonesia. Recently, beef cattle population in Indonesia reached more than 11 million heads, with the percentage of Bali cattle in the population ranging 26-27\%. Based on market information, Bali cattle from Bali deserves a higher price per kg live weight compared to other local or even imported breeds (Diwyanto 2002). This indicates that Bali cattle have good genetic potential and benefit from consumer preference because of a higher carcass percentage and meat quality in line with market requirements. The demand of meat in Indonesia is growing at $6-8 \%$ per annum, greatest in the densely populated and more urbanized areas of Java (Talib et al. 2002). 
Records over the past decades indicate that the size of Bali cattle herd is declining in most areas of the eastern islands as export demand exceeds replacement rate. There is also a widespread view among many scientists that the genetic merit of the genotype may be declining as a consequence of regular and sustained disposal of larger bulls. The average weight of these exported bulls is decreasing (Talib el al. 2002b). Combined with an increasing number of exported females and fattened bulls, this is increasing pressure on the development of Bali cattle. It is important to remember that exported bulls and females are usually the largest and the best animals in the basic population. Thus, both the size and the genetic pool may be decreasing. Beside the above reason, decline in Bali cattle population were also related to high mortality rate before weaning, mainly due to low quality feed and poor management practices.

\section{Reproductive performance and management}

Many reasons exist why farmers and cattle developers are eager to develop this small type of cattle. Despite their adaptation to harsh environments and to be highly efficient in utilizing low quality of feed (Darmadja 1980, Darmadja \& Oka 1980, Martojo 1995), Bali cattle have been reported to be superior to other breeds in fertility and conception rate (Oka \& Darmadja 1996, Toelihere 2002). The fertility rate of Bali cattle reaches around 80\% (Wardoyo, 1950; Devendra et al. 1973, Darmadja 1980) or even up to $90-100 \%$ in Australian conditions (Moran 1971, Kirby 1972). Under harsh dry conditions on the island of Timor, however, the rate was reported about $75 \%$ (Fattah 1998). Some key features from reviews by McCool (1992) and Wirdahayati (1994) and other unpublished information has indicated that Bali cattle, both male and female reach puberty between 12-24 months of age at weight 100-150 $\mathrm{kg}$. The average length of oestrus cycle is 21 days with some evidence that it is shorter when nutrition is poorer (Toelihere 2002). Oestrous is primarily a nocturnal event, with an average duration of 18-19 hours and no evidence of photoperiod effect on cyclicity. Pregnancy occurs after an average of two matings and it has been speculated due to embryonic mortality of at least 30\% (Fordyce et al. 2002) which is normal in the tropics (Holroyd et al. 1993). The gestation period is between 280-290 days with calf birth weight averages about $17 \mathrm{~kg}$ but may be less than $9 \mathrm{~kg}$ in poorly nourished cows. Calf motility rates vary between $2 \%$ and $40 \%$ with higher level occurring in small size calves and if management does not support mothering. However, no detailed studies has been performed so far to prove whether these advantages were related to genetic or mainly causes of poor nutrition management. The relationship of body condition score, response to low quality of feed and its relation to reproductive hormones have not yet been extensively reported.

Breeding is most often based on natural mating by using one or several bulls per herd, the latter to compensate for eventual sub-fertility of any other males. This management strategy is widely used but it favours social dominance, especially when bull age is not uniform in the group of sires. Since dominant, older bulls are likely to win more mating opportunities than younger bulls, any case of infertility in these sires will have a major impact on the fertility of the herd. Considering the utmost role of the bulls on the reproductive efficiency of the cattle herd, there is a need to implant routines to screen their potential reproductive capacity, either already in use as breeders and, perhaps as important, for the young sires to be introduced in the breeding herd, so that potentially low-fertile bulls are withdrawn from breeding.

\section{Strategies for implementation of breeding programmes}

There is limited or no structure in the breeding system being used at present in Bali cattle industry. The breeding is, in general term, random with no objective selection criteria and with only minimum subjective selection of breeding animals (Lindsay and Entwistle, 2002). 
There are limited data available to support the perception that there may be negative selection for major traits because the best animals phenotypically are often sold for slaughter at high process or used for cross breeding, while the less suitable smaller animals are kept for breeding. Regardless of the present status of breeding of Bali cattle, there are strong arguments for initiating a systematic genetic improvement program. Artificial insemination (AI) is practiced in Bali island, west and east Nusa Tenggara and south Sulawesi. The frozen semen is provided by Singosari AI centre at Malang, west Java. Bali beef competes in the market with beef from other cattle breed, local and imported, and many of these breeds now have effective improvement program in place. The competitiveness of Bali cattle will decrease over time unless they too, are subjected to selection for improved productivity (Lindsay and Entwistle, 2002). In some traits, Bali cattle have a strong inherent competitive advantage that should be preserved and developed. Given good nutrition and management, the Bali breed is probably more fecund than other cattle breed under the same condition. Bali cattle also have some competitive disadvantage and these traits could be improved genetically. In most cases where growth rates were measured, they were low compared with those of other breeds, suggesting that this would be a major selection trait in any organized breeding program. In addition, Jembrana disease, a unique and lethal retroviral infection affecting Bali cattle may be a candidate for marker assisted genetic selection, a trait that could be included in a future breeding program.

\section{Conservation and maintenance of genetic diversity in Banteng and Bali cattle}

As already exposed, because Banteng can interbreed with common cattle, there are questions about the purity of the genetic status of the wild and captive remaining population. There is a possibility that even zoological garden populations may contain genetic material from Bali cattle/Bos taurus crosses. There is an obvious need to disclose the genetic status of the remaining Banteng population, in order to allow the safe collection and cryobanking of pure genetic material for future generations. Such rationale is valid also for Bali cattle. With more than $26 \%$ of the beef cattle population, Bali cattle diversity is not a major problem. However, a systematic genetic improvement programme for Bali cattle in the eastern islands of Indonesia and Bali designed to improve the economic well-being of cattle farmers in the region has included the use of AI with frozen-thawed semen. Screening at one of the AIcentres responsible for the production of AI-semen doses, using specific genetic markers on samples from the bull sires providers of the semen, showed that half of these were not pure Bali (Noor, unpublished results). Therefore, there is an urgent need to continue to scrutinize males to be recruited as AI-bull sires so that a warranty of genetic purity is established.

\section{Breeding soundness of bull sires}

The role of the bull on the reproductive efficiency of the cattle herd is well known. Impairment of bull fertility results in great economic losses, particularly in extensive cattle production where the breeding scheme consists of several bulls for a group of females. Therefore, the use of basic techniques of breeding soundness evaluation, including male breeding behaviour, clinical examination and semen evaluation as a whole, to screen potential fertility of bulls have proved useful for identification of males with low potential fertility (Chacón 2000). Age at attainment of puberty is a parameter of major relevance when considering selection of breeding animals. Age of attainment of puberty depends on many factors, e.g. breed, nutrition, management, environment etc. Studies concerning the reproductive development of bulls under field conditions in Indonesia are limited. There are evidences of seasonal effect on semen quality in Bos taurus bulls raised in temperate climate 
zones (Parkinson 1987, Chase et al. 1993) and also under tropical conditions (Kumi-Diaka et al. 1981, Chacón 2000). Seasonal effects on the semen quality of Bali bulls are scarce. Low scrotal circumference (as indicator of low sperm production and eventual hypoplasias) appears among the most common underlying reasons for un-soundness followed by the presence of high percentages of abnormal spermatozoa (Chacón et al. 1999). Both sperm production and the deliverance of normal spermatozoa are prerequisites, along with normal body constitution, for the sound recruitment of bulls for breeding. Semen assessment has developed enormously over the past decades, and simple assays can currently be done to determine sperm quality (reviewed by Rodriguez-Martinez 2007). Among these evaluation methods for bull semen there are several of basic nature, as sperm morphology and motility patterns, that -under controlled conditions- correlate with the potential fertility of the scrutinized bulls, due to the positive relationship of sperm morphology with testicular and epididymal function. However, there is a need for an on-farm evaluation procedure of the collected semen that does not involve laborious laboratory-staining and detailed microscopy assessment, but such methodology has to be firmly established in order to corroborate the clinical assessment included in the breeding soundness evaluation scheme.

\section{Acknowledgements}

Supported by the Swedish Research Council (VR), Stockholm, Sweden.

\section{Corresponding author's address}

Dr. Bambang Purwantara, Department of Veterinary Clinic, Reproduction and Pathology, Faculty of Veterinary Medicine, Bogor Agricultural University (IPB), Jl. Agatis Kampus IPB Darmaga, Bogor-Indonesia (Phone/Fax +62-251-629461, E-mail: b.purwantara@ biotrop.org)

\section{Conflicts of interest}

Nothing to declare.

\section{References}

Chacón J, 2000: Breeding soundness evaluation of zebu bulls. Paper IV. Doctoral thesis. SLU, Uppsala, Sweden.

Chacón J, Pérez E, Müller E, Söderquist L, Rodríguez-Martínez H, 1999: Breeding soundness evaluation of extensively managed bulls in Costa Rica. Theriogenology 52 221-231.

Chase CC Jr, Larsen RE, Hammond AC, Randel RD, 1993: Effect of dietary energy on growth and reproductive characteristics of Angus and Senepol bulls during summer in Florida. Theriogenology 40 43-61.

Darmadja D, 1980: Half century of traditional Bali cattle farming in Baliness agricultural ecosystem. Doctoral Thesis, Padjadjaran University, Bandung.

Darmadja D, Oka IGL, 1980: Bali cattle and its colour variation. Proc. $6^{\text {th }}$ congress of Federation of Animal Veterinary Association. 16-19 Oct 1980, Denpasar, Bali. 
Devendra CT, Choo LK, Pathmasingan M, 1973: The productivity of Bali cattle in Malaysia. Malaysian Agric J 49 183-197.

Diwyanto K, 2002: Introduction of workshop on Bali cattle : Strategies to Improve Bali cattle in eastern Indonesia. Proc. Workshop on Strategies to Improve Bali Cattle in Eastern Indonesia. Udayana Eco Lodge Denpasar Bali 4-7 February 2002

Fattah S, 1998: Productivitas sapi Bali yang dipelihara di padang penggembalaan alam (Kasus Oesu'u NTT). (The productivity of Bali cattle kept in natural pasture (Case study in Oesu'u, East Nusatenggara). Doctoral Thesis. Padjajaran University. Bandung.

Fordyce G, Panjaitan T, Muzani, Poppi D, 2002: Management to facilitate genetic improvement of Bali cattle in eastern Indonesia. Proc. Workshop on Strategies to Improve Bali Cattle in Eastern Indonesia. Udayana Eco Lodge Denpasar Bali 4-7 February 2002

Handiwirawan E, Noor RR, Muladno L, Schueler L, 2003: The use of HEL9 and INRA 035 Microsatelites as specific markers for Bali Cattle. Arch Tierz Dummerstorf 46 503-512.

Holroyd RG, Entwistle KW, Shepherd RK, 1993: Effects on reproduction of estruos cycle variation, rectal temperatures and liveweights in mate $\mathrm{d}$ Brahman cross heifers. Theriogenology 40 453-464.

Kirby GWM, 1972: Bantengs, a new source of genes. Turn Off 46.

Kirby GWM, 1979: Bali cattle in Australia. World Animal Rev 31 2-7.

Kumi-Diaka J, Nagaratnam V, Rwuaan JS, 1981: Seasonal and age-related changes in semen quality and testicular morphology of bulls in a tropical environment. Vet Rec 108 13-15.

Martojo H, 1995: The distribution of Bali cattle in the past. Ruminansia 49.

McCool C, 1992: Buffalo and Bali cattle - exploiting their reproductive behaviour and physiology. Trop Anim Health Prod 24 165-172

Moran JB, 1971: Advance in Northern cattle breeds. Chiasma 959.

Noor RR, Farajallah A, Karmita M, 2001: The purity test of Bali cattle by haemoglobin analysis using the isoelectric focusing method. Hayati 8107-111.

Nowak RM (ed), 1991: Walker's Mammals of the World (5 ${ }^{\text {th }}$ Edition), Baltimore: The Johns Hopkins University Press.

Oka L, Darmadja D, 1996: History and development of Bali of Bali cattle. Proc. Seminar Bali cattle a special species for the dry tropics. 21 September 1996. Udayana Lodge, Bukit Jimbaran Bali.

Parkinson TJ, 1987: Seasonal variations in semen quality of bulls: Correlations with e environmental temperature. Vet Rec 120 479-482. 
Rodriguez-Martinez H, 2007: State of the art in farm animal sperm evaluation. Reprod Fertil Dev 19 91-101.

Taib C, Entwistle K, Siregar A, Budiarti-Turner S, Lindsay D, 2002: Survey of population and production dynamics of Bali cattle and existing breeding programs in Indonesia. Bali cattle Workshop. Udayana Eco Lodge Denpasar Bali 4-7 February 2002.

Talib C, Siregar AR, Budiarti-Turner S, Diwyanto K, 2002: Implementation of a breeding program for Bali cattle. Technical issues at national and regional levels. Workshop on Strategies to Improve Bali Cattle in Eastern Indonesia. Udayana Eco Lodge Denpasar Bali 4-7 February 2002.

Toelihere M, 2002: Increasing the success rate and adoption of artificial insemination for genetic improvement of Bali cattle. Workshop on Strategies to Improve Bali Cattle in Eastern Indonesia. Udayana Eco Lodge Denpasar Bali 4-7 February 2002.

Wardoyo M, 1950: Peternakan sapi di Sulawesi Selatan (Cattle farming in South Sulawesi) Hemera Zoa 56 116-118.

Wirdahayati RB, 1994: Reproductive characteristics and productivity of Bali and Ongole cattle in Nusa Tenggara, Indonesia. PhD thesis. The University of Queensland.

Wilson DE, Reeder DM (eds), 1993: Mammal Species of the World (2 ${ }^{\text {nd }}$ Ed). Washington: Smithsonian Institution Press. Available online at http://www.si.edu/msw/ 